\title{
Synthesis, Urease Inhibition, Antioxidant and Antibacterial Studies of Some 4-Amino-5-aryl-3H-1,2,4-triazole-3-thiones and their 3,6-Disubstituted 1,2,4-Triazolo[3,4-b]1,3,4-thiadiazole Derivatives
}

\author{
Muhammad Hanif, ${ }^{a}$ Muhammad Saleem, ${ }^{a}$ Muhammad Tahir Hussain, ${ }^{b}$ \\ Nasim Hasan Rama, *,a Sumera Zaib, ${ }^{c}$ Muhammad Adil M. Aslam, ${ }^{c}$ \\ Peter G. Jones ${ }^{d}$ and Jamshed Iqbal*,c \\ ${ }^{a}$ Department of Chemistry, Quaid-i-Azam University, Islamabad 45320, Pakistan \\ ${ }^{b}$ Department of Applied Sciences, national textile university, Faisalabad 37610, Pakistan \\ 'Department of Pharmaceutical Sciences, COMSATS Institute of Information Technology \\ Abbottabad 22060, Pakistan \\ ${ }^{d}$ Institute for Inorganic and Analytical Chemistry, Technical University of Braunschweig, \\ Hagenring 30, 38106 Braunschweig, Germany
}

Uma nova série de 4-amino-5-aril-3H-1,2,4-triazol-3-tionas, tendo vários grupos metoxibenzila e metoxifenila, foi sintetizada através de refluxo de sais de hidrazina carboditioato de potássio em solução aquosa diluída de hidrato de hidrazina. Estes sais foram formados pela reação de hidrazinas ácidas e dissulfeto de carbono em solução de hidróxido de potássio metanólico a 0-5 ${ }^{\circ} \mathrm{C}$. 4-Amino-5-aril-3H-1,2,4-triazol-3-tionas foram condensadas com diferentes ácidos aromáticos substituídos para produzir 1,2,4-triazol[3,4-b]1,3,4-tiodiazols 3,6-disubstituídos. As estruturas dos compostos sintetizados foram caracterizadas pelas espectroscopias no infravermelho (IR) e ressonância magnética nuclear (NMR) de ${ }^{1} \mathrm{H} \mathrm{e}{ }^{13} \mathrm{C}$, análise elementar e espectrometria de massa (MS). Todos os compostos sintetizados foram examinados com relação as suas atividades de inibição de urease, antioxidante e antibacteriana. Alguns compostos mostraram excelente atividade de inibição de urease, mais do que a droga padrão. Outros compostos apresentaram potente atividade antioxidante. Todos os compostos mostraram atividades antibacterianas significativas em comparação com a droga padrão.

A new series of 4-amino-5-aryl-3H-1,2,4-triazole-3-thiones, bearing various methoxybenzyl- and methoxyphenethyl groups, was synthesized by refluxing potassium hydrazinecarbodithioate salts in dilute aqueous solution of hydrazine hydrate. These salts were formed by the reaction of acid hydrazides and carbon disulfide in methanolic potassium hydroxide solution at $0-5{ }^{\circ} \mathrm{C}$. 4-Amino5-aryl-3H-1,2,4-triazole-3-thiones were condensed with different substituted aromatic acids to yield 3,6-disubstituted-1,2,4-triazolo[3,4-b]1,3,4-thiadiazoles. The structures of the synthesized compounds were characterized by infrared (IR), ${ }^{1} \mathrm{H}$ and ${ }^{13} \mathrm{C}$ nuclear magnetic resonance (NMR), elemental analysis and mass spectrometric (MS) studies. All the synthesized compounds were screened for their urease inhibition, antioxidant and antibacterial activities. Some compounds showed excellent urease inhibition activity, more than the standard drug. Others exhibited potent antioxidant activity. All the compounds showed significant antibacterial activities as compared to the standard drug.

Keywords: amino-1,2,4-triazoles, triazolothiadiazoles, urease inhibitors, antioxidants, antibacterial activity

*e-mail: nhrama@qau.edu.pk, drjamshed@ciit.net.pk 


\section{Introduction}

Urease (urea amidohydrolase, E.C. 3.5.1.5) is an enzyme that catalyzes the hydrolysis of urea to ammonia and carbamate, which is the final step of nitrogen metabolism in living organisms. ${ }^{1,2}$ Carbamate rapidly and spontaneously decomposes, yielding a second molecule of ammonia. These reactions may cause significant increase in $\mathrm{pH}$ and are responsible for negative effects of urease activity in human health and agriculture. Urease is responsible for urinary tract and gastrointestinal infections, ${ }^{3}$ possibly causing severe diseases such as peptic ulcers and stomach cancer as in the case of Helicobacter pylori. ${ }^{4}$ Ureases are also involved in the development of urolithiasis, pyelonephritis, hepatic encephalopathy, hepatic coma and urinary catheter encrustation. ${ }^{5}$

The efficiency of soil nitrogen fertilization with urea (the most used fertilizer worldwide) decreases due to ammonia volatilization and root damage caused by increased soil $\mathrm{pH} .{ }^{6}$ Control of the activity of urease through the use of inhibitors could counteract these negative effects.

Reactive oxygen species (ROS), which are capable of causing damage to DNA, have been associated with carcinogenesis, coronary heart diseases and many other health problems related to advancing age. ${ }^{7,8}$ In low concentrations, synthetic antioxidants are also in use for many industrial processes, e.g. inhibition of radical formation for preventing premature polymerization during processing, storage and transportation of unsaturated monomers. They exert their effects by scavenging or preventing the generation of ROS, ${ }^{9}$ protecting the formation of free radicals and retarding the progress of many chronic diseases,${ }^{10}$ including cancer, neurodegenerative, inflammation and cardiovascular diseases. ${ }^{11}$

Recently, 5-substituted-4-amino-1,2,4-triazole3 -thiones and their fused triazolothiadiazole derivatives have received considerable attention owing to their synthetic and potent pharmacological importance. Heterocyclic compounds bearing 1,2,4-triazole nuclei and their triazolothiadiazole derivatives have been reported to show a broad spectrum of pharmacological properties such as antimicrobial, ${ }^{12}$ anti-inflammatory,,$^{13}$ anticonvulsant, ${ }^{14}$ anticancer, ${ }^{15}$ antitubercular ${ }^{16}$ and antitumor activities. ${ }^{17}$

Literature survey reveals that 5-substituted-4-amino1,2,4-triazoles and their 3,6-disubstituted-1,2,4-triazolo[3,4-b]-1,3,4-thiadiazole derivatives have not been paid much attention for their enzymatic inhibition studies. Hence, the present studies were undertaken to explore the urease inhibition potential of 5-substituted-4-amino1,2,4-triazoles and their fused triazolothiadiazole derivatives. In this work, we report the synthesis, urease inhibition studies, antioxidant and antibacterial activities of 5-substituted-4-amino-1,2,4-triazole and 3,6-disubstituted1,2,4-triazolo-[3,4-b]-1,3,4-thiadiazoles.

\section{Experimental}

All the common solvents and chemicals were of analytical grade or purified by distillation. The purity of the synthesized compounds was ascertained by thin layer chromatography (TLC) and the $\mathrm{R}_{f}$ values were determined by employing pre-coated silica gel aluminum plates (Kieselgel $60 \mathrm{~F}_{254}$ from Merck (Germany)), using petroleum ether:EtOAc (8:2) as an eluent. The spots were visualized under an UV lamp. Melting points (mp) were determined on a Stuart melting point apparatus (SMP3) and are uncorrected. The infrared (IR) spectra were recorded on a Bruker Optics Alpha FTIR spectrophotometer. Nuclear magnetic spectra (NMR) spectra were recorded on a Bruker Avance $300 \mathrm{MHz}$ spectrometer with TMS (tetramethylsilane) as internal standard. The multiplicities were expressed as $\mathrm{s}=$ singlet, $\mathrm{d}=$ doublet, $\mathrm{t}=$ triplet, $\mathrm{q}=$ quartet, $\mathrm{dt}=$ doublet of triplets. Mass spectra (MS) were recorded on Agilent Technologies 6890N gas chromatograph and an inert mass selective detector 5973 mass spectrometer. The elemental analysis was performed on Leco CHNS-932 Elemental Analyzer, Leco Corporation (USA).

General procedure for synthesis of substituted aromatic esters (2a-e) and aromatic acid hydrazides (3a-e)

Substituted aromatic acids (1a-e) were esterified (2a-e) by refluxing in methanol and in the presence of catalytic amount of sulfuric acid. Substituted aromatic esters (2a-e) were converted into their corresponding acid hydrazides 3 by refluxing in hydrazine hydrate in methanol through literature procedure. ${ }^{18-20}$

General procedure for synthesis of 3-substituted 4-amino5-aryl-3H-1,2,4-triazole-3-thiones (5a-e)

Aryl hydrazide 3 ( $0.125 \mathrm{~mol})$ was added to a solution of potassium hydroxide $(0.125 \mathrm{~mol})$ in dry methanol $(50 \mathrm{~mL})$ and cooled in ice. Carbon disulfide $(0.125 \mathrm{~mol})$ was then added in small portions with constant stirring. The solid product of potassium dithiocarbazinate $\mathbf{4}$ formed was filtered, washed with chilled diethyl ether and dried. It was directly used for next step without purification. The above potassium dithiocarbazinate $\mathbf{4}$ was taken in water $(20 \mathrm{~mL})$, and hydrazine hydrate $(0.250 \mathrm{~mol})$ was added followed by reflux for $4-5 \mathrm{~h}$. The reaction mixture turned 
green with evolution of hydrogen sulphide and finally it became homogeneous. It was then poured in ice and acidified with concentrated hydrochloric acid. The white precipitate was filtered, washed with cold water and recrystallized from aqueous methanol.

General procedure for synthesis of 3,6-disubstituted $[1,2,4]$ triazolo[3,4- $b][1,3,4]$ thiadiazoles $(\mathbf{6 a - 0})$

A mixture 3-substituted 4-amino-1,2,4-triazole 5 $(1 \mathrm{mmol})$ and substituted benzoic acid $(1.1 \mathrm{mmol})$ in phosphorous oxychloride $(10 \mathrm{~mL})$ was refluxed for 6-7 $\mathrm{h}$. The reaction mixture was slowly poured into crushed ice with stirring and neutralized with solid sodium bicarbonate. The solid material was filtered, washed with cold water, dried and recrystallized from chloroform.

\section{Pharmacological assays}

\section{Urease inhibition bioassay}

The synthesized compounds were screened for their urease inhibition activity, which is shown in Table 1. The compounds were found inhibiting the urease in variable concentrations. Thiourea was used as reference compound.

The urease activity was determined by measuring the amount of ammonia being produced using the indophenol

Table 1. Urease inhibition activities $\left(\mathrm{IC}_{50}\right.$ and $\left.\mathrm{K}_{\mathrm{i}}\right)$ of compounds (5a-e) and (6a-o)

\begin{tabular}{lcc}
\hline Compound & $\mathrm{IC}_{50} / \mu \mathrm{M}$ & $\mathrm{K}_{\mathrm{i}}$ \\
\hline Thiourea & $26 \pm 5$ & $21 \pm 5$ \\
$\mathbf{5 a}$ & $2.25 \pm 0.023$ & $1.30 \pm 0.01$ \\
$\mathbf{5 b}$ & $0.85 \pm 0.03$ & $0.49 \pm 0.05$ \\
$\mathbf{5 c}$ & $2.08 \pm 0.03$ & $1.20 \pm 0.01$ \\
$\mathbf{5 d}$ & $1.93 \pm 0.02$ & $1.11 \pm 0.02$ \\
$\mathbf{5 e}$ & $9.1 \pm 1.7$ & $5.3 \pm 1.1$ \\
$\mathbf{6 a}$ & $\mathrm{NS}^{\mathrm{a}}$ & - \\
$\mathbf{6 c}$ & $\mathrm{NS}^{\mathrm{a}}$ & - \\
$\mathbf{6 e}$ & $\mathrm{NS}^{\mathrm{a}}$ & - \\
$\mathbf{6 f}$ & $5.5 \pm 1.2$ & $3.18 \pm 0.67$ \\
$\mathbf{6 g}$ & $\mathrm{NS}^{\mathrm{a}}$ & - \\
$\mathbf{6 h}$ & $15 \pm 4$ & - \\
$\mathbf{6 i}$ & $10 \pm 3$ & - \\
$\mathbf{6 j}$ & $5.0 \pm 0.7$ & - \\
$\mathbf{6 k}$ & $10 \pm 3$ & - \\
$\mathbf{6 1}$ & $\mathrm{NS}^{\mathrm{a}}$ & - \\
$\mathbf{6 m}$ & $\mathrm{NS}^{\mathrm{a}}$ & - \\
$\mathbf{6 n}$ & $\mathrm{NS}^{\mathrm{a}}$ & - \\
$\mathbf{6 0}$ & $1.55 \pm 0.16$ & $8.96 \pm 1.30$ \\
\hline
\end{tabular}

${ }^{\mathrm{a} N S}$ : not soluble; ${ }^{\mathrm{N} D}$ : not determined. method described by Weatherburn. ${ }^{21}$ The assay mixture, containing $10 \mu \mathrm{L}$ of enzyme $\left(5 \mathrm{U} \mathrm{mL}^{-1}\right)$ and $10 \mu \mathrm{L}$ of test compound in $40 \mu \mathrm{L}$ buffer $\left(100 \mathrm{mmol} \mathrm{L}^{-1}\right.$ urea, $0.01 \mathrm{~mol} \mathrm{~L}^{-1}$ $\mathrm{K}_{2} \mathrm{HPO}_{4}, 1 \mathrm{mmol} \mathrm{L}^{-1} \mathrm{EDTA}$ and $0.01 \mathrm{~mol} \mathrm{~L}^{-1} \mathrm{LiCl}_{2}, \mathrm{pH} 8.2$ ), were incubated for $30 \mathrm{~min}$ at $37^{\circ} \mathrm{C}$ in 96 -well plates. Briefly, $40 \mu \mathrm{L}$ each of phenol reagents $(1 \%, \mathrm{~m} / \mathrm{v}$ phenol and $0.005 \%, \mathrm{~m} / \mathrm{v}$ sodium nitroprusside) and $40 \mu \mathrm{L}$ of alkali reagent $(0.5 \%, \mathrm{~m} / \mathrm{v} \mathrm{NaOH}$ and $0.1 \%$ active chloride $\mathrm{NaOCl})$ were added to each well. The absorbance at $625 \mathrm{~nm}$ was measured after $30 \mathrm{~min}$, using a microplate reader (Bio-Tek ELX $800^{\mathrm{TM}}$, Instruments, Inc. USA). All the reactions were performed in triplicate. Percentage inhibition was calculated by using the following equation.

Inhibition $(\%)=100-\frac{\mathrm{Abs}_{\text {test well }}}{\mathrm{Abs}_{\text {control }}} 100$

Thiourea was used as the standard inhibitor of urease. The Cheng-Prusoff equation was used to calculate the $\mathrm{K}_{\mathrm{i}}$ values from the $\mathrm{IC}_{50}$ values, determined by the non-linear curve fitting program PRISM 4.0 (GraphPad, San Diego, California, USA). At $37{ }^{\circ} \mathrm{C}, 1 \mu \mathrm{mol}$ of ammonia being produced per min by enzyme is known as one unit of enzyme at $\mathrm{pH}$ 8.2.

\section{Antioxidant activity (DPPH scavenging assay)}

The synthesized compounds were screened for antioxidant activity, which is shown in the Table 2. The compounds have shown hydrogen-donating ability on reaction with DPPH (1,1-diphenyl-2-picrylhydrazyl) radical. Propyl gallate was used as standard drug.

The free radical scavenging capacity of the compounds was measured by modified 1,1-diphenyl-2-picrylhydrazyl methods described by Choudhary et al. ${ }^{22}$ Test compounds were allowed to react with stable free radical, 1,1-diphenyl2-picrylhydrazyl radical, for $30 \mathrm{~min}$ at $37{ }^{\circ} \mathrm{C}$. The concentration of DPPH was kept as $100 \mathrm{mmol} \mathrm{L}^{-1}$. The test samples were dissolved in DMSO (dimethyl sulfoxide) while the DPPH solution was prepared in ethanol. After incubation, the decrease in absorption was measured at $515 \mathrm{~nm}$ using multiplate reader (Spectra MAX-384). Percent radical scavenging activity (RSA) of samples was determined in comparison with a DMSO treated control group ${ }^{23,24}$ using the following formula (Table 2):

$\operatorname{RSA}(\%)=100-\frac{\mathrm{Abs}_{\text {test compound }}}{\mathrm{Abs}_{\text {control }}} 100$

\section{Antibacterial activity}

The synthesized compounds were screened for antibacterial activity, which is shown in the Table 3. The 
Table 2. DPPH radical scavenging activities of the synthesized compounds (5a-e) and (6a-o)

\begin{tabular}{|c|c|c|c|}
\hline Compound & $\begin{array}{l}\text { Concentration / } \\
\left(\mu \mathrm{g} \mathrm{mL}^{-1}\right)\end{array}$ & RSA / \% & $\mathrm{IC}_{50} / \mu \mathrm{M}$ \\
\hline $5 \mathbf{a}$ & 0.5 & 60.6 & 108.6 \\
\hline $5 b$ & 0.5 & 54.4 & 57.2 \\
\hline $5 c$ & 0.5 & 58.5 & 155.6 \\
\hline $5 d$ & 0.5 & 52.3 & 51.8 \\
\hline $5 e$ & 0.5 & 59.8 & 113.0 \\
\hline $6 a$ & 0.5 & 44.9 & 36.8 \\
\hline $6 \mathrm{~b}$ & 0.5 & 56.3 & 223.1 \\
\hline $6 c$ & 0.5 & 56.7 & 390.6 \\
\hline $6 d$ & 0.5 & 63.1 & 785.4 \\
\hline $6 e$ & 0.5 & 15.2 & 9.04 \\
\hline $6 f$ & 0.5 & 33.1 & 35.3 \\
\hline $6 \mathrm{~g}$ & 0.5 & 59.8 & 501.5 \\
\hline $6 h$ & 0.5 & 51.4 & 69.2 \\
\hline $6 \mathbf{i}$ & 0.5 & - & - \\
\hline $6 \mathbf{j}$ & 0.5 & - & - \\
\hline $6 \mathrm{k}$ & 0.5 & 58.2 & 423.1 \\
\hline 61 & 0.5 & - & - \\
\hline $6 \mathrm{~m}$ & 0.5 & 62.2 & 431.7 \\
\hline $6 n$ & 0.5 & 29.5 & 34.7 \\
\hline 60 & 0.5 & 59.9 & 264.4 \\
\hline Standard (n-propyl gallate) & 0.5 & 92.5 & 40.8 \\
\hline
\end{tabular}

RSA: radical scavenging activity; -: not determined.

compounds were found active against bacterial strains in variable concentration. Ciprofloxacin was used as standard drug.

The antibacterial activities of all the synthesized derivatives were evaluated in vitro by serial tube dilution method. For antibacterial activity, two gram positive bacterias namely Staphylococcus aureus and Bacillus subtilis, and two gram negative bacteria namely Escherichia coli and Shigella flexneri were used.

The compounds and standard drug ciprofloxacin were dissolved in $N, N$-dimethylformamide (DMF) to give a concentration of $5 \mu \mathrm{g} \mathrm{mL}^{-1}$ (stock solution). A set of test tubes of capacity $5 \mathrm{~mL}$ was washed, cleaned and dried completely. Double strength nutrient broth was used as a growth/culture media for all bacteria. The culture media was made by dissolving $15 \mathrm{~g}$ of nutrient broth No. 2 in $1 \mathrm{~L}$ of distilled water. Approximately $1 \mathrm{~mL}$ of culture media was prepared and transferred to each test tube by micropipette and capped with non-adsorbent cotton plugs. A set of test tubes containing $1 \mathrm{~mL}$ culture media was sterilized in an autoclave at 15 psi pressure at $121{ }^{\circ} \mathrm{C}$ for $20 \mathrm{~min}$. Sub-culturing of bacteria was done by transferring a loopful of particular bacterial strain from standard bacterial agar slant to $10 \mathrm{~mL}$ sterilized nutrient broth aseptically in a laminar air flow cabinet. It was then incubated for a period of $24 \mathrm{~h}$ at $37^{\circ} \mathrm{C}$ in a B.O.D. incubator. Bacterial stain suspension was prepared (after $24 \mathrm{~h}$ incubation) by aseptically inoculating $0.2 \mathrm{~mL}$ of revived bacterial colony into $100 \mathrm{~mL}$ of $0.9 \% \mathrm{~m} / \mathrm{v}$ saline. The study involved a series of 5 assay tubes for each compound against each strain. A stock solution of each test compound at concentration $5 \mu \mathrm{g} \mathrm{mL}^{-1}$ was serially diluted in series of 5 assay test tubes (containing $1 \mathrm{~mL}$ nutrient broth) to give concentration of $2.5,1.25,0.625,0.313$ and $0.156 \mu \mathrm{g} \mathrm{mL}^{-1}$. Then, $0.1 \mathrm{~mL}$ of normal saline suspension of revived bacteria was added to each test tube. The inoculated tubes were incubated at $37^{\circ} \mathrm{C}$ for $24 \mathrm{~h}$. The MIC (minimum inhibitory concentration) values were determined by subsequently checking for the absence of visual turbidity. ${ }^{25}$

\section{Results and Discussion}

\section{Chemistry}

The synthesis of the target compounds, 1,2,4-triazolo[3,4-b]1,3,4-thiadiazoles (6a-o), is illustrated in Scheme 1. Substituted aromatic esters (2a-e) were synthesized by the reaction of the corresponding substituted aromatic acids (1a-e) with methanol in the presence of catalytic amount of sulfuric acid. These esters (2a-e) were converted to the corresponding aromatic acid hydrazides (3a-e) by refluxing with hydrazine hydrate $(80 \%)$ in methanol. Syntheses of hydrazides (3a-e) were confirmed by IR and NMR spectroscopies. In the IR spectrum, the typical doublet absorption in the range of $3296-3338 \mathrm{~cm}^{-1}$ and a peak in the range of $3204-3214 \mathrm{~cm}^{-1}$ for primary and secondary amines, respectively, were observed. The ${ }^{1} \mathrm{H}$ NMR exhibited a singlet in the range of 9.16-9.96 ppm for NH proton, next to the carbonyl group. A broad singlet for two protons for $\mathrm{NH}_{2}$ group in the range of $\delta$ 4.16-4.46 indicated the formation of hydrazides (3a-e). The reaction of acid hydrazides (3a-e) with carbon disulfide in alcoholic potassium hydroxide solution yielded potassium hydrazinecarbodithioate salts (4a-e), which were used for the next step without purification. 5-Substituted4-amino-1,2,4-triazoles (5a-e) were synthesized by refluxing potassium hydrazinecarbodithioate salts (4a-e) in dilute solution of hydrazine hydrate. Structures of amino 1,2,4-triazoles (5a-e) were characterized by IR, NMR and mass spectrometry. In IR spectra, a relatively strong peak in the range of $3327-3249 \mathrm{~cm}^{-1}$ for $\mathrm{NH}_{2}$ stretching and a peak in the range of $3105-3202 \mathrm{~cm}^{-1}$ for $\mathrm{NH}$ stretching were observed. In the ${ }^{1} \mathrm{H}$ NMR, NH proton in the range of 13.71-13.44 ppm was observed. This proton exists as thione-thiol tautomeric form. The dominant form is 
Table 3. In vitro antibacterial activity of (5a-e) and (6a-o)

\begin{tabular}{|c|c|c|c|c|}
\hline \multirow{2}{*}{ Compound } & \multicolumn{4}{|c|}{$\mathrm{MIC} /\left(\mu \mathrm{g} \mathrm{mL} L^{-1}\right)$} \\
\hline & Escherichia coli & Bacillus subtilis & Staphylococcus aureus & Shigella flexner \\
\hline $5 a$ & 0.313 & 0.313 & 0.313 & 0.156 \\
\hline $5 \mathbf{b}$ & 0.625 & 0.313 & 0.313 & 0.313 \\
\hline $5 c$ & 0.313 & 0.625 & 0.313 & 0.313 \\
\hline $5 d$ & 0.313 & 0.313 & 0.313 & 0.156 \\
\hline $5 e$ & 0.625 & 0.313 & 0.625 & 0.156 \\
\hline $6 a$ & 0.313 & 0.625 & 0.313 & 0.156 \\
\hline 6b & 0.313 & 0.313 & 0.313 & 0.313 \\
\hline $6 c$ & 0.313 & 0.313 & 0.313 & 0.625 \\
\hline 6d & 0.313 & 0.156 & 0.156 & 0.313 \\
\hline $6 e$ & 0.313 & 0.156 & 0.156 & 0.313 \\
\hline 6f & 0.156 & 0.313 & 0.313 & 0.313 \\
\hline $6 \mathrm{~g}$ & 0.625 & 0.313 & 0.156 & 0.156 \\
\hline $6 \mathrm{~h}$ & 0.156 & 0.313 & 0.313 & 0.313 \\
\hline $6 \mathbf{i}$ & 0.156 & 0.313 & 0.156 & 0.156 \\
\hline $6 k$ & 0.313 & 0.313 & 0.313 & 0.313 \\
\hline $6 \mathrm{~m}$ & 0.156 & 0.313 & 0.156 & 0.156 \\
\hline $6 n$ & 0.313 & 0.156 & 0.156 & 0.313 \\
\hline 60 & 0.156 & 0.156 & 0.156 & 0.313 \\
\hline Ciprofloxacin & 0.156 & 0.625 & 0.156 & 0.313 \\
\hline
\end{tabular}

thione as there was no peak for the SH group in the IR spectrum, and this is further confirmed by single crystal. Two NH protons appeared in the range of $5.54-5.59 \mathrm{ppm}$.

\section{Pharmacology}

\section{Urease inhibition bioassay}

Almost all the compounds showed excellent urease inhibition more than the standard inhibitor determined through the standard urease assay. ${ }^{21}$ 4-Amino-5-aryl3H-1,2,4-triazole-3-thiones (5a-e) were more active than their 3,6-disubstituted 1,2,4-triazolo-[3,4-b]1,3,4-thiadiazole (6a-o) derivatives. Among 4-amino5-aryl-3H-1,2,4-triazole-3-thiones (5a-e), compound $\mathbf{5 b}$ with $\mathrm{IC}_{50} 0.85 \pm 0.02 \mu \mathrm{M}$ was the most active and all other compounds of this series showed activities with $\mathrm{IC}_{50}$ ranging from $1.93 \pm 0.01$ to $9.11 \pm 1.70 \mu \mathrm{M}$. Compound $\mathbf{6 o}$, of 3,6-disubstituted- 1,2,4-triazolo-[3,4-b]-1,3,4-thiadiazole series, was the most active with $\mathrm{IC}_{50} 1.55 \pm 0.16 \mu \mathrm{M}$. The rest of the compounds showed inhibition with $\mathrm{IC}_{50}$ ranging from $5 \pm 1$ to $15 \pm 4 \mu \mathrm{M}$. The most active compound of 5 series, $\mathbf{5 b}$ has ortho-methoxybenzyl group attached with amino-1,2,4-triazole moiety. The most active compound of 6 series has 2,5-dimethoxy group in X part and orthomethyl group in $\mathrm{Y}$ part.

Despite identifying compounds with excellent inhibitory activities, it was observed that some compounds got precipitated in our standard urease assay media. These compounds are under investigation.

\section{Antioxidant activity}

Compounds $\mathbf{5 b}, \mathbf{5 d}, \mathbf{6 a}, \mathbf{6}$ and $\mathbf{6 n}$ with the $\mathrm{IC}_{50}$ values $57.2,51.8,36.8,35.3$ and $34.7 \mu \mathrm{M}$, respectively, have shown hydrogen donating ability on reaction with DPPH radical. It is clear from the results that the antioxidant potential of the compounds is associated with the position of the substituents on the ring Y. In compounds $\mathbf{5} \mathbf{b}$ and 5d, chloro group is present at position 2 and 4 in $\mathrm{X}$ ring. Whereas in 6a, 6f and 6n halogenated substituents are present in ring Y. Among 4-amino-5-aryl-3H-1,2,4-triazole3-thiones (5a-e), compound $\mathbf{5 d}$ with $\mathrm{IC}_{50} 51.8 \mu \mathrm{M}$ was most active and all other compounds of this series showed activities with $\mathrm{IC}_{50}$ ranging from 57.2 to $155.6 \mu \mathrm{M}$. The triazolothiadiazole class of compounds was found to be significantly active against superoxide anion radical. The compound 6e with an $\mathrm{IC}_{50}$ value $9.04 \mu \mathrm{M}$ was found to be most active at such a low concentration, even low than standard. The activity of $\mathbf{6 e}$ is enhanced in this class due to the presence of methoxy group at position 3 in ring $\mathrm{X}$ while chloro group at position 4 in ring Y. The compounds $\mathbf{5 a}$, $\mathbf{5 c}, 5 \mathbf{e}, \mathbf{6 b}$ and $6 \mathbf{0}$ showed comparable antioxidant potential with the standard, whereas the compound $\mathbf{6 c}, \mathbf{6 d}, \mathbf{6 g}, \mathbf{6 k}$ and 6m showed a moderate superoxide anion scavenging activity. In 4-amino-5-aryl-3H-1,2,4-triazole-3-thiones, 


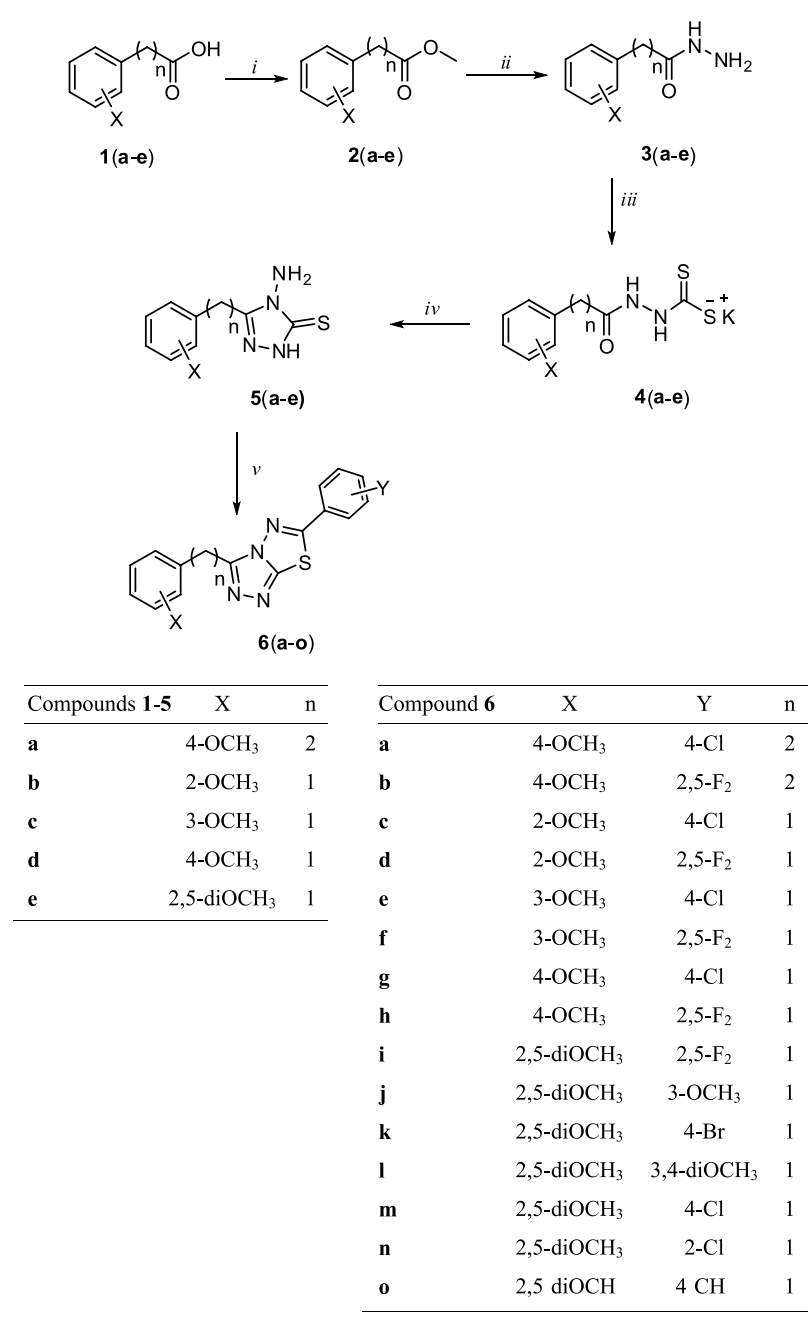

Scheme 1. Reagents and conditions: (i) $\mathrm{MeOH}, \mathrm{H}_{2} \mathrm{SO}_{4}$ (2-3 drops), reflux, (ii) $\mathrm{H}_{2} \mathrm{~N}-\mathrm{NH}_{2} \cdot \mathrm{H}_{2} \mathrm{O}$, reflux, (iii) $\mathrm{KOH}, \mathrm{CS}_{2}, 0-5^{\circ} \mathrm{C}$, (iv) $\mathrm{H}_{2} \mathrm{~N}-\mathrm{NH}_{2} \cdot \mathrm{H}_{2} \mathrm{O}, \mathrm{H}_{2} \mathrm{O}$, reflux, and $(v) \mathrm{POCl}_{3}$, substituted benzoic acids, reflux.

$\mathbf{5 b}$ and 5d along with $\mathbf{6 a}, \mathbf{6 f}$ and $\mathbf{6 n}$ in 3,6-disubstituted 1,2,4-triazolo-[3,4-b]-1,3,4-thiadiazoles (6a-o) derivatives showed $\mathrm{IC}_{50}$ near to the standard and this represents that they are less active.

Antibacterial activity

Almost all the compounds showed excellent antibacterial activity more than or equal to the standard drug ciprofloxacin, determined through the serial tube dilution method. 3,6-Disubstituted 1,2,4-triazolo-[3,4-b]1,3,4-thiadiazoles (6a-o) derivatives were more active than 4-amino-5-aryl-3H-1,2,4-triazole-3-thiones (5a-e). Among 4-amino-5-aryl-3H-1,2,4-triazole-3-thiones (5a-e), compounds $\mathbf{5} \mathbf{a}$ and $\mathbf{5 d}$ were more active against all bacterial strains, especially against Shigella flexneri, and all other compounds of this series showed significant activities for all bacterial strains used. Compounds $\mathbf{6 i}, \mathbf{6 m}$ and $\mathbf{6 o}$ of 3,6-disubstituted- 1,2,4-triazolo-[3,4-b]-1,3,4-thiadiazole series were the most active for almost all bacterial strains. The rest of the compounds showed moderate activities compared to standard drug. Compounds $6 \mathbf{i}$ and $\mathbf{6 m}$ contain fluorine and chlorine group, respectively, whereas 60 contains methyl group in ring Y. Overall most of the compounds in both the series exhibit excellent antibacterial activity as compared to standard drug ciprofloxacin.

\section{Conclusion}

A new series of triazole-3-thione (5a-e) and thiadiazole (6a-0) was synthesized. The urease inhibition ability of these compounds was evaluated. Some of the compounds were found to be excellent inhibitors. The compounds 5a-e, 6f, $6 \mathbf{h}-\mathbf{k}$ and 60 showed remarkable urease inhibition activity, more than the standard drug. The most active inhibitors were 5b and $\mathbf{6 0}$. Therefore, the discovered inhibitors should be further investigated for the control of diseases whose tangible and beneficial alternatives are still insufficient.

The synthesized compounds were also evaluated for their antioxidant ability. The radical scavenging activity of the compounds $5 \mathbf{b}, \mathbf{5 d}, \mathbf{6 a}, \mathbf{6 f}$ and $\mathbf{6 n}$ was significant, being very close to the standard drug. All the newly synthesized compounds were further screened for antibacterial activities, demonstrating that some compounds in the series are most promising. The identified compounds can be utilized for further optimization of bioactivity using structural variations in the parent skeleton.

\section{Supplementary Information}

Supplementary information with characterization data for all compounds and the corresponding spectra of representative compound of each series is available free of charge at http://jbcs.sbq.org.br, as PDF file.

\section{Acknowledgments}

This work was financially supported by COMSTECHTWAS and German-Pakistani Research Collaboration Programme.

\section{References}

1. Mobley, H. L.; Hausinger, R. P.; FEMS Microbiol. Rev. 1989, 53, 85 .

2. Karplus, P. A.; Pearson, M. A.; Hausinger, R. P.; Acc. Chem. Res. 1997, 30, 330.

3. Collins, C. M.; D’Orazio, S. E. F.; Mol. Microbiol. 1993, 9 , 907. 
4. Montecucco, C.; Rappuoli, R.; Nat. Rev. Mol. Cell Biol. 2001, 2,457 .

5. Hausinger, R. P.; Karplus, P. A. In Handbook of Metalloproteins; Messerschmidt, A.; Hubber, R.; Poulos, T.; Wieghardt, K., eds.; John Wiley \& Sons, Chichester, UK, 2001, p. 867-879.

6. Zhengping, W; Van Cleemput, O.; Demeyer, P.; Baert, L.; Biol. Fertil. Soils 1991, 11, 41.

7. Uchida, K.; Free Radical Biol. Med. 2000, 28, 1685.

8. Cadenas, E.; Davies, K. J. A.; Free Radical Biol. Med. 2000, 29, 222.

9. Kinsella, J. E.; Frankel, E.; German, J. B.; Kanner, J.; Food Technol. 1993, 47, 85.

10. Singh, N.; Rajini, P. S.; Food Chem. 2004, 85, 611.

11. Prior, R. L.; Wu, X.; Schaich, K.; J. Agric. Food Chem. 2005, $53,4290$.

12. Karabasanagouda, T.; Adhikari, A. V.; Shetty, N. S.; Eur. J. Med. Chem. 2007, 42, 521.

13. El-Shehry, M. F.; Abu-Hashem, A. A.; El-Telbani, E. M.; Eur. J. Med. Chem. 2010, 45, 1906.

14. Husain, A.; Naseer, M. A.; Sarafroz, M.; Acta Pol. Pharm., Drug Res. 2009, 66, 135.

15. Kamal, A.; Khan, M. N. A.; Reddy, K. S.; Srikanth, Y. V. V.; Sridhar, B.; Chem. Biol. Drug Des. 2008, 71, 78.
16. Joshi, S. D.; Vagdevi, H. M.; Vaidya, V. P.; Gadaginamath, G. S.; Eur. J. Med. Chem. 2008, 43, 1989.

17. Ibrahim, D. A.; Eur. J. Med. Chem. 2009, 44, 2776.

18. Moise, M.; Sunel, V.; Profire, L.; Popa, M.; Desbrieres, J.; Peptu, C.; Molecules 2009, 14, 2621.

19. Shi, W.; Qian, X.; Zhang, R.; Song, G.; J. Agric. Food Chem. 2001, 49, 124.

20. Amir, M.; Shikha, K.; Eur. J. Med. Chem. 2004, 39, 535.

21. Weatherburn, M. W.; Anal Chem. 1967, 39, 971.

22. Choudhary, M. I.; Begum, A.; Abbaskhan, A.; Musharraf, S. G.; Ejaz, A.; Chem. Biodiver. 2008, 5, 2676.

23. Lee, S. K.; Mbwambo, Z. H.; Chung, H.; Luyengi, L.; Gamez, E. J.; Mehta, R. G.; Kinghorn, A. D.; Pezzuto, J. M.; Comb. Chem. High Throughput Screen. 1998, 1, 35.

24. Molyneux, P.; J. Sci. Technol. 2004, 26, 211.

25. Zampini, I. C.; Cuello, S.; Alberto, M. R.; Ordoñez, R. M.; D’Almeida, R.; Solorzano, E.; Isla, M. I.; J. Ethnopharmacol. 2009, 124, 499.

Submitted: September 16, 2011

Published online: April 10, 2012 